\title{
Radiation Induced DNA Double-Strand Breaks in Radiology
}

\section{Strahleninduzierte DNA-Doppelstrangbrüche in der Radiologie}

Authors

Affiliations
M. A. Kuefner ${ }^{1}$, M. Brand ${ }^{2}$, C. Engert ${ }^{2}$, S. A. Schwab ${ }^{3}$, M. Uder ${ }^{2}$

Department of Radiology, Dornbirn Hospital, Austria

Department of Radiology, University Hospital of Erlangen, Germany

Radiologis, Oberasbach, Germany

\section{Key words}

- biological effects

- radiation effects

- radiobiology

radiosensitivity

received 12.2.2015

accepted $\quad 16.5 .2015$

Bibliography

Dol http://dx.doi.org/

10.1055/s-0035-1553209

Published online: 2.9.2015

Fortschr Röntgenstr 2015; 187 :

872-878 @ Georg Thieme

Verlag KG Stuttgart · New York . ISSN 1438-9029

\section{Correspondence}

Priv.-Doz. Dr. Michael Andreas Kuefner

Department of Radiology,

Dornbirn Hospital

Lustenauerstr. 4

6850 Dornbirn

Austria

Tel.: ++43/55 72/3032850

Fax: ++43/55 72/30382850

michael.kuefner@dornbirn.at

\section{Abstract \\ $\nabla$}

Shortly after the discovery of X-rays, their damaging effect on biological tissues was observed. The determination of radiation exposure in diagnostic and interventional radiology is usually based on physical measurements or mathematical algorithms with standardized dose simulations. $\mathrm{y}-\mathrm{H} 2 \mathrm{AX}$ immunofluorescence microscopy is a reliable and sensitive method for the quantification of radiation induced DNA double-strand breaks (DSB) in blood lymphocytes. The detectable amount of these DNA damages correlates well with the dose received. However, the biological radiation damage depends not only on dose but also on other individual factors like radiation sensitivity and DNA repair capacity. Iodinated contrast agents can enhance the $\mathrm{x}$-ray induced DNA damage level. After their induction DSB are quickly repaired. A protective effect of antioxidants has been postulated in experimental studies. This review explains the prinicple of the $\mathrm{y}-\mathrm{H} 2 \mathrm{AX}$ technique and provides an overview on studies evaluating DSB in radiologic examinations.

Key Points:

- Radiologic examinations including CT and angiography induce DNA double-strand breaks. Even after mammography a slight but significant increase is detectable in peripheral blood lymphocytes.

- The number of radiation induced doublestrand breaks correlates well with the radiation dose.

- Individual factors including radiation sensitivity, DNA repair capacity and the application of iodinated contrast media has an influence on the DNA damage level.

Citation Format:

- Kuefner MA, Brand M, Engert C et al. Radiation Induced DNA Double-Strand Breaks in
Radiology. Fortschr Röntgenstr 2015; 187: 872-878

\section{Zusammenfassung}

$\nabla$

Der schädigende Effekt von Röntgenstrahlung auf biologische Gewebe ist bereits seit langem bekannt. Die Bestimmung der Dosisbelastung in der diagnostischen und interventionellen Radiologie erfolgt in erster Linie mithilfe physikalischer Verfahren anhand standardisierter Phantome oder mit mathematischen Dosissimulationen. Mit der Y-H2AX-Immunfluoreszenzmikroskopie steht seit einigen Jahren ein sehr sensitives Verfahren zur Quantifizierung strahleninduzierter DNA-Doppelstrangbrüche (DSB) in Blutlymphozyten zur Verfügung. Der messbare Strahlenschaden an der DNA korreliert hier sehr gut mit der deponierten Dosis. Andererseits werden jedoch auch individuelle Faktoren, wie z. B. die Strahlensensibilität oder die DNA-Reparatur berücksichtigt. Jodhaltige Kontrastmittel können den strahleninduzierten DNASchaden verstärken. Nach der Induktion werden die DSB rasch repariert. Mit neuen Ansätzen ist es sogar möglich, den DNA-Schaden in einzelnen Organen abzuschätzen. Erste experimentelle Studien postulieren einen protektiven Effekt von Antioxidantien. Diese Übersichtsarbeit beschreibt das Prinzip der $\mathrm{y}$-H2AX-Methode und gibt einen Überblick über die die wichtigsten Ergebnisse der bisher publizierten Studien, in denen während radiologischer Untersuchungen induzierte DSB untersucht wurden.

\section{Background}

Shortly after the discovery of X-ray radiation, its detrimental effect on biological tissue was observed. The increasing number of X-raybased examinations in recent decades has re- 
sulted in the heightened importance of radiation dosage and protection as clinical topics [1, 2]. Determination of dose exposure in diagnostic and interventional radiology is carried out primarily using physical methods based on standardized phantoms or relying on mathematical dosage simulations. Such estimates can determine the exposure quite well, but supply no information regarding the interaction of radiation in the patient's body. Nowadays there are indications that biological radiation damage is not solely dependent on the applied dosage, but is also related to additional individual factors that cannot be sufficiently determined using established dosimetric methods. Earlier approaches to biological dosimetry were not sensitive enough for the dosage range used in radiology [3].

Double-stand breaks (DSB) are considered the most relevant radiation-induced damage to deoxyribonucleic acid (DNA) [4]. Although such breakage is quickly repaired, defective repairs can result in mutations, causing carcinogenesis $[5,6]$.

An immunofluorescence microscopic approach, which is much more sensitive than previous biological processes, allows the determination of individual DNA DSB in peripheral blood lymphocytes, thus allowing an accurate estimation of the biological radiation damage in the radiological dose range. In the meantime, 10 years have passed since this method was first employed to measure radiation-induced DSB after in-vivo exposure in the course of radiological examinations [7]. Since then, numerous studies have been published describing radiation-induced DSB in diagnostic and interventional radiology as well as in cardiology. This article provides an overview of previously published data and summarizes the current state of knowledge.

\section{Y-H2AX immunofluorescence microscopy}

After induction of DNA DSB, one of the earliest cell responses is phosphorylation several thousand molecules of the histone variant H2AX [8]. Using specific primary and fluorescent secondary antibodies in the form of point-like signals, called foci, this phosphorylated histone $(\mathrm{y}-\mathrm{H} 2 \mathrm{AX})$ can

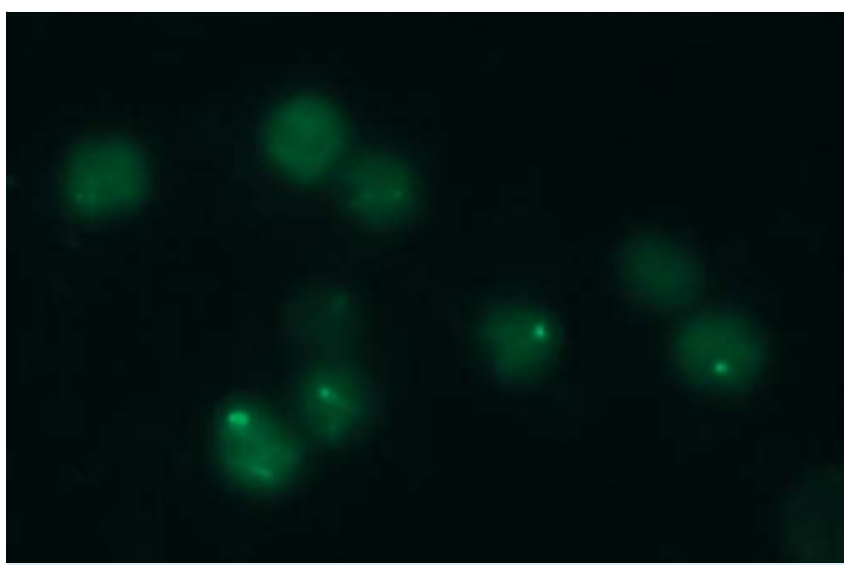

Fig. 1 Example of $\mathrm{Y}-\mathrm{H} 2 \mathrm{AX}$ foci in isolated blood lymphocytes (100x magnification objective) of a patient who underwent cardiac CT using a lowpitch protocol: the tiny green spots within the cells are termed foci, each focus represnets one DNA double-strand break (own figure). be visualized using fluorescence microscopy ( $\bullet$ Fig. 1 ) $[3,9$, 10].

Lymphocytes from the patients' whole blood can be isolated using gradient centrifugation which can then best be used for in-vivo exposure. After repeated washing, fixing, permeabilizing and dyeing with the relevant antibodies, the $y$ H2AX foci can be quantified using a fluorescence microscope. Each focus corresponds to one DSB. The number of foci is a function of the quantity of enumerated cells. The number of radiation-induced double-strand breaks is calculated based on subtraction of control values determined pre-exposition from the post-exposition values; in most studies these are called "excess foci" [7].

After radiation exposure, DSB induction results in a rapid increase in foci; in several studies the highest number is achieved within minutes and correlates well with the applied dose [9]. Compared to earlier approaches to biological dosimetry such as pulsed-field gel electrophoresis or the identification of chromosomal damage, $\mathrm{y}-\mathrm{H} 2 \mathrm{AX}$ immunofluorescence microscopy is much more sensitive and allows detection of radiation-induced DNA damage both after in-vitro as well as post in-vivo exposure with a dose of only $1 \mathrm{mGy}$ $[9,11]$. Thus this method is applicable in the dosage range of both $\mathrm{CT}$ and interventional radiological procedures.

The so-called blood dose can be calculated based on the excess foci. To do this, the patients' blood samples must be irradiated in-vitro with a defined dose. Using the values thus obtained, the number of excess foci induced per $\mathrm{mGy}$ can be calculated. The corresponding blood dose can be obtained if the in-vivo values are applied here [11].

\section{Radiation-induced DNA double-strand breaks during radiology}

\section{DSB after CT}

An initial investigation of DNA DSB of patients after computed tomography (CT) of the thorax and/or abdomen as well as one case of a skull CT demonstrated a significant increase

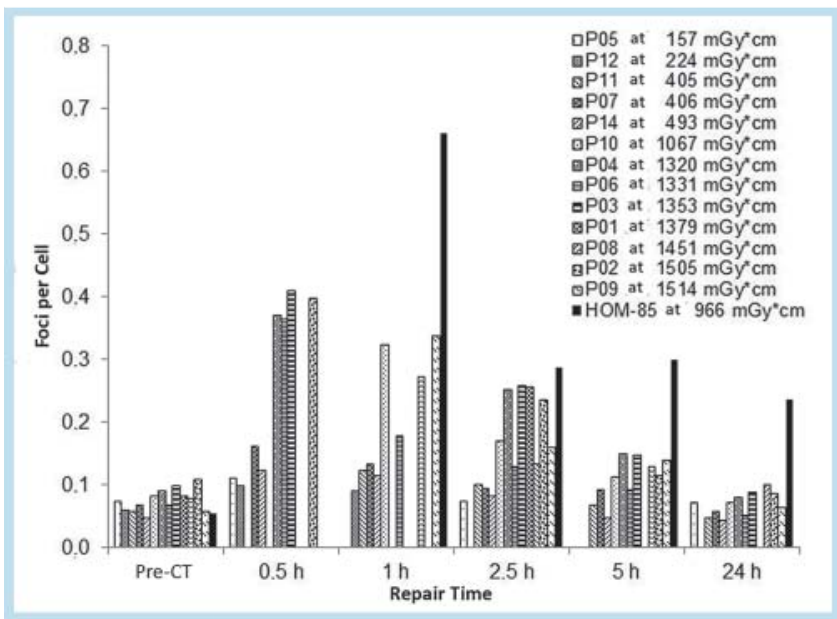

Fig. $2 \mathrm{y}-\mathrm{H} 2 \mathrm{AX}$ foci kinetics in blood lymphocytes of patients before and after chest and/or abdominal CT examinations: blood samples were obtained from 14 patients before and at particular times after the CT scan. Dose length products are shown for every patient (figure based on data from ref [7]). 
of the pre-exposure level 30 minutes post-CT; afterward the DSB values rapidly dropped due to repair, and after 24 hours the initial values were again achieved (0 Fig. 2). The number of CT-induced double-strand breaks correlated well with the dose-length product, although the correlation coefficient was higher 30 minutes post-exposure $\left(R^{2}=0.9626\right)$ than after 60 minutes $\left(R^{2}=0.7117\right)$. It can be concluded, therefore, that different patients repair DSB at different rates [7]. In one case, a patient with a comparable CT dose-length product exhibited significantly greater DSB than the rest of the study cohort. This patient had earlier undergone radiotherapy and had experienced very strong side effects; subsequently defective DNA repair was diagnosed, which accounted for the higher DNA DSB [7]. This illustrates that individual radiation damage is not dependent on the applied dosage alone, but is also dependent upon additional individual factors such as the personal capacity to self-repair.

Shortly afterward, a further study confirmed DSB inducement after CT. Here, the highest DSB values were measured 5 minutes after radiation exposure; afterward there was a rapid repair-related drop in values within 30 minutes of the examination. The average biological dose was $16.4 \mathrm{mGy}$ during thoracic-abdominal-pelvic CT, significantly higher than $6.3 \mathrm{mGy}$ after a thoracic CT [12].

An investigation of patients after ${ }^{18} \mathrm{~F}$-FDG PET/CT likewise demonstrated a significant correlation between CT-induced DSB and dose-length product [13].

However, a non-linear relationship between the number of CT-induced foci and blood dose calculated using Monte Carlo simulation was demonstrated by two studies. One concerned adult patients with thoracic or abdominal CT, the other was described in a recently-published multi-center study by the same research group, involving 51 pediatric patients in 5 centers who had undergone thoracic or abdominal CT [14, 15]. A steep rise in the curve was shown in the dose range up to $2 \mathrm{mGy}$ [14] and up to $10 \mathrm{mGy}$ [15]; then the curve flattened. Consequently the authors presumed hypersensitivity in the low-dose range. In addition, linear regression analysis demonstrated that the number of induced double-strand breaks per mGy declined with the patients' age [15]. Age-dependent differences in detectable levels of $\mathrm{Y}-\mathrm{H} 2 \mathrm{AX}$ foci are well-known, but there are little published data in this regard. Currently it cannot be explained whether the observed age-dependency is due to differing radiosensitivity or different rates of DSB repair.

\section{DSB after cardiac CT}

Due to technical advances in $\mathrm{CT}$ in recent years, manufacturers of CT systems are increasingly offering reduced-dose examination protocols and scanning modalities [16]. This is particularly significant with respect to coronary CT angiography, since conventional helical scans of a small examination region result in a relative high dose of radiation. ECGtriggered sequential scan modes ("Step and Shoot") or helical examinations with a very high pitch above 3 ("Flash CT") which allow imaging of the entire heart in a fraction of a second should result in dosage reduction [17].

Three studies by the Erlangen Working Group each noted significant correlation between radiation-induced DSB and dose-length product and the derived effective dose (৫ Fig.3). Compared to helical scans with low pitch, pro-

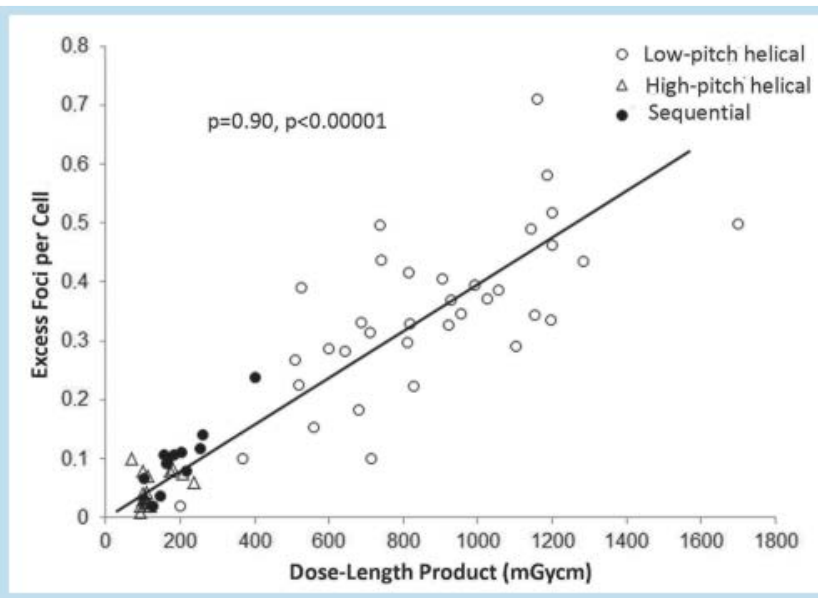

Fig. $3 \mathrm{Y}$-H2AX foci in blood lymphocytes after cardiac $\mathrm{CT}$ : blood samples were obtained before and 30 minutes after the $\mathrm{CT}$ scan, the difference between pre- and post-exposure values represents the amount of $\mathrm{CT}$ induced DSB (excess foci). Various scan modes are graphically differentiated (circles: low-pitch helical scan, tirangles: high-pitch helical scan, black dots: sequential scan). Spearman correlation $(\rho)$ is shown, $p<0,05$ was considered statistically significant (figure based on data from refs. [11, 18]).

spective ECG-triggered sequential scans as well as examination with a pitch $>3$ resulted in a significant reduction of CT-induced DSB, where a reduction by a factor of 10 was achieved using Flash CT $[11,18,19]$. A reduction of tube voltage to $100 \mathrm{kV}$ likewise resulted in a significant reduction of radiation-induced DSB when compared to $120 \mathrm{kV}$ protocols [19]. It is interesting to note that in one study DSB values normalized to the DSB values demonstrated a significant correlation with the density level of blood in the heart and large vessels in the scanned region [18]. This is an indication that iodine-based contrast agents can lead to increased radiation-induced DSB (see below).

In a randomized study, a cardiac CT was compared to diagnostic cardiac catheterization with respect to biological effects upon DNA. A prospective triggered scan using a 320slice CT (entire heart in one scan without table movement) induced significantly fewer DSB than a cardiac catheterization $(0.12 \pm 0.06$ vs. $0.29 \pm 0.18, p<0.001)$. Using both examination methods, DNA damage significantly correlated with the effective dose estimated using conversion factors based on the dose-length product and dose-area product (CT: $r=0.951$, cardiac catheter: $r=0.862)[20]$.

\section{DSB and iodine-based contrast media}

A further individual factor is the intravenous administration of iodine-based contrast media. In-vitro experiments showed that using the same radiation dose, significantly more DNA DSB was measurable in samples with contrast agents compared to those without contrast media or samples after incubation with various control substances. Adding contrast agent directly after the sample was irradiated had no effect on the quantity of DSB; this indicates that the effect may be due to increased induction rather than reduced repair. In the same study, these results were confirmed in-vivo in patients examined using thoracic CT; at a comparable dose after contrast-enhanced CT radiation damage was about $30 \%$ higher than after native examina- 
tions. It can be assumed that a cause of increased DSB as a response to contrast media can be an enhanced photoelectric absorption in the iodine atoms in the medium and consecutive exposure of adjacent lymphocytes [21].

Another study cast doubt on the effect of contrast agents due to in-vitro tests. However, these experiments were conducted with a very small group of subjects $(n=3)$, and the baseline values were higher by a factor of about 10 than otherwise published, so that the reliability of these results is uncertain in our opinion [14].

On the other hand, a current publication has confirmed an increase in DNA damage in a cohort of patients that have undergone chest CT [22].

\section{DSB after angiography}

Angiography is likewise of particular interest since the exposure conditions differ significantly from other radiological procedures such as CT. X-rays are not administered once in a brief timeframe, but are fractionated over a longer period. A linear dependence of DSB induction related to dose-area product $(r=0.993)$ was found among patients who had undergone percutaneous transluminal angioplasty of the arteries of the lower extremity. The DSB were repaired quickly, the initial values measured prior to exposure ( 0.04 foci/cell) were not completely achieved ( 0.07 foci/cell) within 24 hours, however [23]. An increase in DSB was likewise shown after cardiac catheterization in children; the induced $y-\mathrm{H} 2 \mathrm{AX}$ foci in the low-dose range up to $5 \mathrm{mGy}$, however, correlated non-linearly with the blood dose determined using Monte Carlo simulation. In this instance the authors, similarly to the CT studies above, presume hypersensitivity in the low-dose range [24]. Two other studies demonstrated that the repair kinetics of DSB should be taken into account, especially due to fractionated radiation exposure during intervention, otherwise a repair-related underestimate of the actual radiation damage will result. In these studies, radiation-induced DSB did not correlate well with the dose-area product in the entire cohort after angiography of various vascular regions. However, a separate consideration of the various examined bodily regions resulted in very good correlation coefficients (e.g. $r=0.71$ for pelvis-leg angiography, $\mathrm{r}=0.96$ for abdominal angiography) Normalized to the individual dose-area product, significant differences were shown for the individual examination regions; the degree of damage was the highest for cardiac catheterization, followed by abdominal interventions, angiography of the pelvic-leg circulatory pathway and the cerebrum. These differences can be explained by the varying blood volumes of the different body regions and the associated various quantities of exposed lymphocytes $[25,26]$. One of these studies also demonstrated that chemotherapy itself induces DNA damage, thus distorting the actual radiation damage [25].

\section{Assessment of DSB in tissue}

The dependence on exposed blood volume also illustrates one of the limitations of $\mathrm{y}-\mathrm{H} 2 \mathrm{AX}$ immunofluorescence microscopy, since under some circumstances, this method shows its shortcomings particularly with respect to radiation exposure of body regions with low blood volume. The female breast is an organ with low blood volume, for example. However, in a cohort of patients having had mammo- grams of both breasts on two planes, a small yet highly significant increase of DSB in blood lymphocytes was measured (median 0.086 vs. 0.094 foci/cell, $p=0.0004$ ). Due to mixing with unexposed blood, these values underestimate the radiation damage in exposed tissue. In order to assess local damage, as part of the experimental setting of this study, cells in a natural phantom (porcine breast) were therefore irradiated using a mammography unit. A mean 0.035 foci/cell were induced during localization at glandular level [27]. Additional semi-biological phantom models (e.g. cell exposure in an Alderson phantom) are conceivable in order to assess the biological damage to various organs.

\section{Protection by radical scavengers?}

Since DNA damage is caused by free radicals, the protective effect of antioxidants is quite conceivable. Various studies using in-vitro or animal experiments in the past demonstrated that some radical scavengers can reduce radiationinduced DNA damage [28 - 32].

In a study published in Radiology, a commercially available mixture of substances with antioxidant effect (vitamin C, vitamin E, carotenoids, $\mathrm{N}$-acetylcysteine, alpha-lipoic acid, selenmethionine) was tested on human blood lymphocytes using $\mathrm{y}-\mathrm{H} 2 \mathrm{AX}$ immunofluorescence microscopy [33]. In-vitro experiments with blood from volunteers that was incubated with antioxidants and irradiated with $10 \mathrm{mGy}$ exhibited significantly fewer $\mathrm{y}-\mathrm{H} 2 \mathrm{AX}$ foci compared to samples that were not pretreated $(\mathrm{p}<0.0001)$.

Since additional factors affect in-vivo testing, such as oral bioavailability and catabolism of antioxidants which are irrelevant to in-vitro experiments, combined in-vivo/in-vitro investigations were additionally performed. After blood samples were taken, each subject received a capsule of the antioxidant preparation, and additional blood samples were obtained at various junctures starting 15 minutes after ingestion up to 5 hours post-ingestion. All samples were again irradiated with 10 mGy. Compared to the samples taken prior to oral ingestion, post-ingestion samples demonstrated significant reduction of measurable radiation-induced DSB at all intervals. After 60 minutes, reduction was $58 \%$ ( $\bullet$ Fig. 4) [33].

A follow-up study investigated individual radical scavengers and described the significant effect of $\mathrm{N}$-acetylcysteine. Other substances such as vitamin C, vitamin E, beta-carotene, Q10 and L-selenmethionine had a reduced effect on radiation-induced $\mathrm{Y}-\mathrm{H} 2 \mathrm{AX}$ foci, whereas zinc and lipoic acid showed no effect. A combination of different substances did not improve the effect, which is likely due to a saturation effect [34].

A recently published placebo-controlled double-blind study was the first to investigate the effect of vitamin $C$ and $\mathrm{N}$-acetylcysteine on $\mathrm{Y}$-H2AX foci in patients who had undergone low-dose coronary CT or cardiac catheterization. In each instance, pretreatment with antioxidants resulted in reduction of radiation-induced $\mathrm{y}-\mathrm{H} 2 \mathrm{AX}$ foci compared to patients receiving a placebo. The effect of vitamin $\mathrm{C}(-87 \%)$ should be higher than for $\mathrm{N}$-acetylcysteine $(-43 \%$, $\mathrm{p}=0.005)$ [35].

The results are quite promising. However, it remains to be seen whether the effects of antioxidants are based on reduced induction rather than interference of the substances with phosphorylation of the H2AX histone. It should addi- 


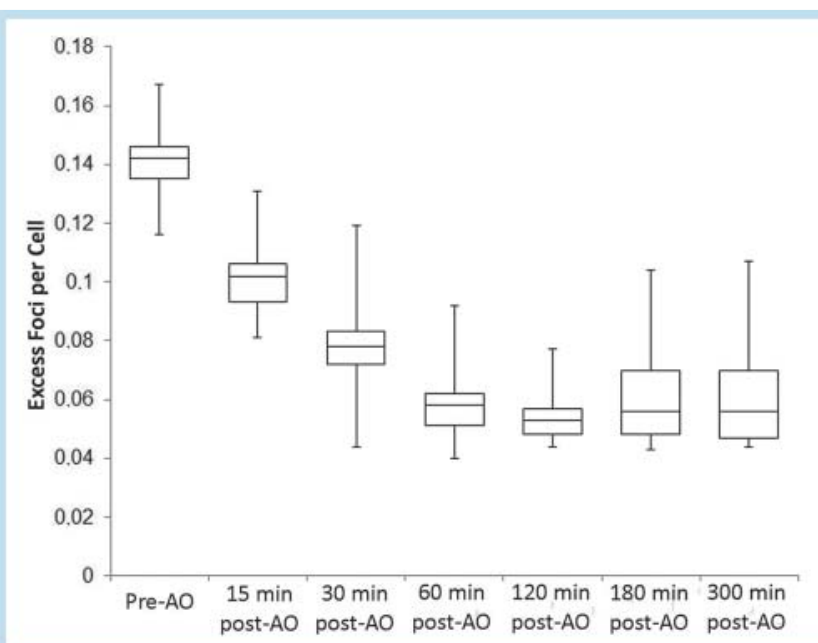

Fig. 4 Effect of antioxidants on $\mathrm{y}-\mathrm{H} 2 \mathrm{AX}$ foci: for combined in-vivo/in-vitro experiments blood samples were obtained from 17 healthy volunteers before, $15,30,60,120,180$, and 300 minutes after oral ingestion of a commercially available antioxidant formulation (AO). Samples were irradiated with $10 \mathrm{mGy}$ in-vitro and incubated for 5 minutes. Excess foci represent radiation induced DSB. Boxes show interquartile ranges, middle horizontal lines represent medians, and the error bars indicate the ranges. $P$ value for Dunnetts' test was $<0.0001, p<0,05$ was considered statistically significant (figure based on data from ref. [33]).

tionally be emphasized that based on existing data on this topic, influence on the risk of carcinogenesis remains unclear, and that further studies are required.

\section{Kinetic aspects}

$\nabla$

Each person has an individual $\mathrm{y}-\mathrm{H} 2 \mathrm{AX}$ foci baseline apart from medical radiation exposure. In the case of blood lymphocytes, a range of $0.05-0.15$ per cell have been described ( $\bullet$ Table 1 ). DSB induction results in a rapid increase of measurable foci; in some studies the highest values have been measured 5 minutes after exposure [12, 13, 23]. This quantity of radiation-induced foci demonstrate a dependence on the dose, which in most in-vitro and in-vivo studies was linear [7, 9, 13, 23, 33]. Individual studies described non-linear relationships $[14,15,24]$. However, it should be noted that in this working group, the baseline values were higher by a factor of 10 ( $\bullet$ Table 1 ). It remains uncertain todate, to what extent this affects the measurable foci, as well as the exact underlying reasons for the hypersensitivity. After reaching a peak, the foci values fall rapidly due to repair; in some studies the baseline value is achieved again after 24 hours. Nevertheless, the rate of incorrectly repaired breaks is uncertain, since this cannot be ascertained using this method. Further, due to rapid DSB repair, it is quite possible to underestimate the actual radiation damage, since under some circumstances, the breaks have already been repaired at the time of measurement. Use of the phosphatase inhibitor calyculin A has been shown to be helpful in this regard since it inhibits dephosphorylation of $\mathrm{y}-\mathrm{H} 2 \mathrm{AX}$, and at least ex-vivo, prevents the rapid decline of measurable foci values [36].

\section{Limitations of the method}

$\nabla$

Despite its excellent sensitivity, $\mathrm{y}-\mathrm{H} 2 \mathrm{AX}$ immunofluorescence microscopy has a few disadvantages [37].

Although in the meantime the generally accepted opinion is that $\mathrm{y}-\mathrm{H} 2 \mathrm{AX}$ foci equate to DSB, however they can also appear during the formation of micronuclei, changes in the chromatin structure, or in the course of normal replication $[9,37]$. These effects should not play a relevant role, since in most of the cited studies, non-replicating lymphocytes were used.

Quantification of $\mathrm{Y}-\mathrm{H} 2 \mathrm{AX}$ foci represents an indirect method for determining DSB. However, sensitive direct methods are not available in the dose range used in radiology.

The method is very time-consuming, thus measurement of large patient populations is very difficult. In this instance, automated counting of foci would be an advantage, even to exclude inter-individual differences during manual quantification. Currently special software packages are available, yet in our experience, they have limited reliability with respect to the doses relevant to our study. In general, $\mathrm{y}-\mathrm{H} 2 \mathrm{AX}$ can be quantified using flow cytometry, which would allow automated measurement. On the other hand, the literature indicates that the sensitivity of this method is $0.1-0.3 \mathrm{~Gy}$, and thus lies outside the radiological dose range [38]. An ELISA is likewise not sensitive enough.

The extent of the influence of methodological factors such as antibodies produced by different manufacturers or the fluorescence microscope employed is still unclear.

Patient-specific factors such as diseases associated with changes to lymphocytes (e.g. lymphoma, infection) or various therapies (e.g. chemotherapy, radiotherapy) can also falsify measurable values. Such patients have been excluded in most cited studies.

Further, due to rapid DSB repair, it is quite possible to underestimate the actual radiation damage (see above).

\section{Conclusions}

$\nabla$

$\mathrm{Y}$-H2AX immunofluorescence microscopy is a very sensitive method of reliably measuring radiation-induced DNA double-strand breaks in the dose range of diagnostic and interventional radiology. Induction of DSB correlates well with the applied dose, but due to the influence of individual factors such as radio sensitivity, capacity to repair, and application of iodine-based contrast media can be likewise be considered. Individual adaptation of the examination protocols appears to be useful, since individual examination parameters have a considerable influence on DNA damage. The extent of the influence of antioxidants on the risk of radiation-induced cancer remains unclear despite their presumed protective effect, and should be investigated in future studies. 
Table 1 Overview of previously published studies in which $\mathrm{y}-\mathrm{H} 2 \mathrm{AX}$ was measured in patients after radiological examinations.

\begin{tabular}{|c|c|c|c|c|c|c|c|}
\hline publication & examination method & $\mathbf{n}$ & background & time of meas- & radiation-induced fo & ci/cell ${ }^{1}$ & correlation $^{3}$ \\
\hline Lobrich (PNAS 2005) & CT of trunk & 23 & $0.05-0.11$ & $30 \mathrm{~min}$ & & $\begin{array}{l}\text { approx. } 0.03- \\
0.31\end{array}$ & $R^{2}=0.9626$ \\
\hline $\begin{array}{l}\text { Rothkamm et al. } \\
\text { (Radiology 2007) }\end{array}$ & CT of trunk & 12 & $0.06 \pm 0.01$ & $5 \mathrm{~min}$ & $\begin{array}{l}\text { thorax-abdomen: } \\
\text { thorax: }\end{array}$ & $\begin{array}{l}0.52 \pm 0.02 \\
0.24 \pm 0.04\end{array}$ & n. a. \\
\hline $\begin{array}{l}\text { Geisel et al. (Radiology } \\
\text { 2008) }\end{array}$ & PTA $(+\mathrm{CT})$ & 25 & $0.04 \pm 0.01$ & $5 \mathrm{~min}$ & $\begin{array}{l}\text { PTA } \\
\text { CT }\end{array}$ & $\begin{array}{l}\text { approx. } 0.41^{4} \\
\text { approx. } 0.11- \\
0.43^{4}\end{array}$ & $\begin{array}{l}r=0.993 \\
r=0.997\end{array}$ \\
\hline $\begin{array}{l}\text { Kuefner et al. } \\
\text { (RöFo 2009) }\end{array}$ & angiography & 31 & $0.02-0.22$ & $15 \mathrm{~min}$ & & $0.01-1.50$ & $R^{2}=0.71-0.96$ \\
\hline $\begin{array}{l}\text { Kuefner et al. (Invest } \\
\text { Radiol 2009) }\end{array}$ & angiography & 19 & $0.02-0.22$ & $15 \mathrm{~min}$ & & $0.03-1.50$ & $R=0.79$ \\
\hline $\begin{array}{l}\text { Grudzenski et al. } \\
\text { (Radiology 2009) }\end{array}$ & CT of thorax & 37 & approx. 0.1 & $30 \mathrm{~min}$ & & $0.09-0.36$ & n. a. \\
\hline $\begin{array}{l}\text { Beels et al. (Circulation } \\
\text { 2009) }\end{array}$ & CC (pediatric) & 49 & approx. 0.5 & "shortly after" & & approx. $0.1-0.8$ & nonlinear \\
\hline $\begin{array}{l}\text { Kuefner et al. (Invest } \\
\text { Radiol 2010) }\end{array}$ & CT of heart & 34 & $0.04-0.15$ & $30 \mathrm{~min}$ & $\begin{array}{l}\text { high-pitch } \\
\text { low-pitch }\end{array}$ & $\begin{array}{l}0.02-0.10(0.04) \\
0.22-0.71(0.39)\end{array}$ & $\rho=0.82$ \\
\hline $\begin{array}{l}\text { Kuefner et al. } \\
\text { (Eur Radiol 2010) }\end{array}$ & CT of heart & 36 & $0.04-0.16$ & $30 \mathrm{~min}$ & $\begin{array}{l}\text { helical } \\
\text { sequential }\end{array}$ & $\begin{array}{l}0.18-0.71(0.37) \\
0.04-0.24(0.11)\end{array}$ & $\rho=0.81$ \\
\hline $\begin{array}{l}\text { Brand et al. (Eur J Radi- } \\
\text { ol 2011) }\end{array}$ & CT of heart & 66 & $0.04-0.16$ & $30 \mathrm{~min}$ & $\begin{array}{l}\text { low-pitch } \\
\text { high-pitch } \\
\text { sequential }\end{array}$ & $\begin{array}{l}0.02-0.71(0.34) \\
0.01-0.10(0.03) \\
0.02-0.24(0.10)\end{array}$ & $\rho=0.90$ \\
\hline $\begin{array}{l}\text { Beels et al. (Eur J Radiol } \\
\text { 2012) }\end{array}$ & CT of trunk & 69 & n. a. & $5 \mathrm{~min}$ & $\begin{array}{l}\text { scanner } 1 \\
\text { scanner } 2\end{array}$ & $\begin{array}{l}-0.04-1.86 \\
(0.79) \\
0.01-1.38(034)\end{array}$ & nonlinear \\
\hline $\begin{array}{l}\text { Geisel et al. (Eur Radiol } \\
\text { 2012) }\end{array}$ & $\begin{array}{l}\text { CT of heart and cardiac } \\
\text { catheter }\end{array}$ & 56 & approx. $0.04-0.08$ & $60 \mathrm{~min}$ & $\begin{array}{l}\text { CT } \\
\text { CC } \\
\text { Coronary intervent. }\end{array}$ & $\begin{array}{l}0.12 \pm 0.06 \\
0.29 \pm 0.18 \\
038 \pm 0.08\end{array}$ & $\begin{array}{l}r=0.951 \\
r=0.862\end{array}$ \\
\hline $\begin{array}{l}\text { May et al. (Eur J Nucl } \\
\text { Med Mol Imaging } \\
\text { 2012) }\end{array}$ & ${ }^{18} \mathrm{~F}$-FDG PET-CT & 33 & $0.06-0.12$ & $5 \mathrm{~min}$ & $\begin{array}{l}{ }^{18} \mathrm{~F}-\mathrm{FDG} \text { PET } \\
\mathrm{CT} \text { of trunk } \\
\text { CT legs }\end{array}$ & $\begin{array}{l}0.06-0.27(0.11) \\
0.04-0.54(0.17) \\
0.02-0.08(0.04)\end{array}$ & $\rho=0.898$ \\
\hline $\begin{array}{l}\text { Kuefner et al. (Int J } \\
\text { Radiat Biol 2013) }\end{array}$ & CT of trunk & 7 & $0.11-0.15$ & $5 \mathrm{~min}$ & $\begin{array}{l}\text { without calyculin A } \\
\text { with calyculin A }\end{array}$ & $\begin{array}{l}0.39-0.67 \\
0.61-0.84\end{array}$ & n. a. \\
\hline $\begin{array}{l}\text { Schwab et al. (PLOS } \\
\text { one 2013) }\end{array}$ & mammography & 20 & $0.067-0.116$ & $5 \mathrm{~min}$ & & $\begin{array}{l}0.001-0.026 \\
(0.008)\end{array}$ & n. a. \\
\hline $\begin{array}{l}\text { Stehli et al. (JACC } \\
\text { 2014) }\end{array}$ & $\mathrm{CT}$ of heart and $\mathrm{CC}$ & 59 & n.a. & $\begin{array}{l}\text { "within min- } \\
\text { utes" }\end{array}$ & $\begin{array}{l}\text { CT } \\
\text { coronary intervent. }\end{array}$ & $\begin{array}{l}0.15 \\
0.30\end{array}$ & n. a. \\
\hline $\begin{array}{l}\text { Vandevoorde } \\
\text { (Eur Radiol 2014) }\end{array}$ & $\mathrm{CT}$ of trunk (pediatric) & 51 & $0.23-1.20$ & $5 \mathrm{~min}$ & & $-0.07-0.49$ & nonlinear \\
\hline $\begin{array}{l}\text { Piechowiak et al. } \\
\text { (Radiology 2015) }\end{array}$ & CT of thorax & 245 & $\begin{array}{l}0.073 \pm 0.015 \\
0.071 \pm 0.009\end{array}$ & $\begin{array}{l}\text { "immediately } \\
\text { after" }\end{array}$ & $\begin{array}{l}\text { without CM } \\
\text { with CM }\end{array}$ & $\begin{array}{l}0.027 \pm 0.014 \\
0.056 \pm 0.009\end{array}$ & n. a. \\
\hline
\end{tabular}

$\mathrm{CT}=$ Computer Tomography, PTA = Percutaneous Transluminal Angioplasty, CC = Cardiac Catheterization.

${ }^{1}$ These are either the average \pm standard deviation or value ranges and - if available - mean values. Approximate values indicate values read from graphics, since there are no exact data in the text, or values indicated as approximate in the text.

2 Time values relate to the temporal interval after radiation exposure.

${ }^{3}$ Correlation between radiation-induced foci and dose: Since the correlations are calculated differently in the various studies, differing correlation coefficients are given.

${ }^{4}$ In this study only absolute foci values are indicated.

\section{Acknowledgments}

We would like to thank all staff, doctoral candidates and cooperation partners who have contributed to the data currently available on this topic. Particular thanks go to Prof. Dr. M. Lobrich for his support in numerous scientific questions during the past 10 years as well as Dr. L Distel and his team for their outstanding collaboration in the laboratory.

\section{References}

1 Hricak H, Brenner DJ, Adelstein SJ et al. Managing radiation use in medical imaging: a multifaceted challenge. Radiology 2011; 258: 889-905
2 Brenner DJ. What we know and what we don't know about cancer risks associated with radiation doses from radiological imaging. Br J Radiol 2014; DOI: 10.1259/bjr.20130629

3 Lobrich $M$, Shibata A, Beucher A et al. gammaH2AX foci analysis for monitoring DNA double-strand break repair: strengths, limitations and optimization. Cell Cycle 2010; 9: 662-669

4 van Gent DC, Hoeijmakers JH, Kanaar R. Chromosomal stability and the DNA double-stranded break connection. Nat Rev Genet 2001; 2: 196 206

5 Jeggo PA, Lobrich M. DNA double-strand breaks: their cellular and clinical impact? Oncogene 2007; 26: 7717 -7719

6 Lobrich M, Jeggo PA. The impact of a negligent G2/M checkpoint on genomic instability and cancer induction. Nat Rev Cancer 2007; 7: $861-869$

7 Lobrich M, Rief N, Kuhne $M$ et al. In vivo formation and repair of DNA double-strand breaks after computed tomography examinations. Proc Natl Acad Sci USA 2005; 102: 8984-8989 
8 Rogakou EP, Pilch DR, Orr AH et al. DNA double-stranded breaks induce histone H2AX phosphorylation on serine 139. J Biol Chem 1998; 273 : $5858-5868$

9 Rothkamm K, Lobrich M. Evidence for a lack of DNA double-strand break repair in human cells exposed to very low x-ray doses. Proc Natl Acad Sci USA 2003; 100: 5057-5062

10 Rogakou EP, Boon C, Redon C et al. Megabase chromatin domains involved in DNA double-strand breaks in vivo. J Cell Biol 1999; 146: 905-916

11 Kuefner MA, Hinkmann FM, Alibek $S$ et al. Reduction of X-ray induced DNA double-strand breaks in blood lymphocytes during coronary CT angiography using high-pitch spiral data acquisition with prospective ECG-triggering. Invest Radiol 2010; 45: $182-187$

12 Rothkamm K, Balroop S, Shekhdar J et al. Leukocyte DNA damage after multi-detector row CT: a quantitative biomarker of low-level radiation exposure. Radiology 2007; 242: 244-251

13 May MS, Brand M, Wuest W et al. Induction and repair of DNA doublestrand breaks in blood lymphocytes of patients undergoing ${ }^{18} \mathrm{~F}-\mathrm{FDG}$ PET/CT examinations. Eur J Nucl Med Mol Imaging 2012; 39: 1712 1719

14 Beels L, Bacher K, Smeets P et al. Dose-length product of scanners correlates with DNA damage in patients undergoing contrast CT. Eur J Radiol 2012; 81: 1495 - 1499

15 Vandevoorde C, Franck C, Bacher $K$ et al. $\mathrm{Y}$-H2AX foci as in vivo effect biomarker in children emphasize the importance to minimize $\mathrm{X}$-ray doses in paediatric CT imaging. Eur Radiol 2015; 25: 800-811

16 May MS, Wuest W, Lell MM et al. Current strategies for dosage reduction in computed tomography. Radiologe 2012; 52: 905-913

17 Halliburton SS, Abbara S, Chen MY. Society of Cardiovascular Computed Tomography. et al. SCCT guidelines on radiation dose and dose-optimization strategies in cardiovascular CT. J Cardiovasc Comput Tomogr 2011; 5: $198-224$

18 Kuefner MA, Grudzenski S, Hamann J et al. Effect of CT scan protocols on $\mathrm{x}$-ray-induced DNA double-strand breaks in blood lymphocytes of patients undergoing coronary CT angiography. Eur Radiol 2010; 20: 2917-2924

19 Brand $M$, Sommer M, Achenbach $S$ et al. X-ray induced DNA doublestrand breaks in coronary CT angiography: Comparison of sequential, low-pitch helical and high-pitch helical data acquisition. Eur J Radiol 2012; 81: 357-362

20 Geisel D, Zimmermann E, Rief $M$ et al. DNA double-strand breaks as potential indicators for the biological effects of ionising radiation exposure from cardiac $\mathrm{CT}$ and conventional coronary angiography: a randomised, controlled study. Eur Radiol 2012; 22: 1641 - 1650

21 Grudzenski S, Kuefner MA, Heckmann MB et al. Contrast medium-enhanced radiation damage caused by $\mathrm{CT}$ examinations. Radiology 2009; 253: 706 - 714

22 Piechowiak EI, Peter JF, Kleb B et al. Intravenous Iodinated Contrast Agents Amplify DNA Radiation Damage at CT. Radiology 2015: 132478 [Epub ahead of print]
23 Geisel D, Heverhagen JT, Kalinowski M et al. DNA double-strand breaks after percutaneous transluminal angioplasty. Radiology 2008; 248: $852-859$

24 Beels L, Bacher K, De Wolf D et al. gamma-H2AX foci as a biomarker for patient X-ray exposure in pediatric cardiac catheterization: are we underestimating radiation risks? Circulation 2009; 120: 1903 -1909

25 Kuefner MA, Grudzenski S, Schwab SA et al. DNA double-strand breaks and their repair in blood lymphocytes of patients undergoing angiographic procedures. Invest Radiol 2009; 44: 440-446

26 Kuefner MA, Grudzenski S, Schwab SA et al. X-ray-induced DNA doublestrand breaks after angiographic examinations of different anatomic regions. Fortschr Röntgenstr 2009; 181: 374-380

27 Schwab SA, Brand M, Schlude IK et al. X-ray induced formation of $\mathrm{Y}$ $\mathrm{H} 2 \mathrm{AX}$ foci after full-field digital mammography and digital breasttomosynthesis. PLoS One 2013; 8 (7): e70660. DOI: 10.1371/journal. pone. 0070660

28 Weiss JF, Landauer MR. Protection against ionizing radiation by antioxidant nutrients and phytochemicals. Toxicology 2003; 189: 1-20

29 Reliene R, Pollard JM, Sobol Z et al. N-acetyl cysteine protects against ionizing radiation-induced DNA damage but not against cell killing in yeast and mammals. Mutat Res 2009; 665: 37-43

30 Mansour HH, Hafez HF, Fahmy NM et al. Protective effect of N-acetylcysteine against radiation induced DNA damage and hepatic toxicity in rats. Biochem Pharmacol 2008; 75: 773-780

31 Tiwari P, Kumar A, Balakrishnan S et al. Radiation-induced micronucleus formation and DNA damage in human lymphocytes and their prevention by antioxidant thiols. Mutat Res 2009; 676: 62-68

32 Wan XS, Ware JH, Zhou Z et al. Protection against radiation-induced oxidative stress in cultured human epithelial cells by treatment with antioxidant agents. Int J Radiat Oncol Biol Phys 2006; 64: 1475 - 1481

33 Kuefner MA, Brand M, Ehrlich J et al. Effect of antioxidants on X-ray-induced $\mathrm{Y}-\mathrm{H} 2 \mathrm{AX}$ foci in human blood lymphocytes: preliminary observations. Radiology 2012; 264: 59-67

34 Brand $M$, Vogt $S$, Engert $C$ et al. Auswirkungen von verschiedenen Antioxidantien auf strahleninduzierte DNA-Doppelstrangbrüche. Fortschr Röntgenstr 2013; 185: S215-S216

35 Stehli J, Fuchs TA, Ghadri JR et al. Antioxidants prevent DNA doublestrand breaks from x-ray-based cardiac examinations: a randomized, double-blinded, placebo-controlled trial. J Am Coll Cardiol 2014; 64: $117-118$

36 Kuefner MA, Brand M, Engert $C$ et al. The effect of calyculin A on the dephosphorylation of the histone $\mathrm{y}-\mathrm{H} 2 \mathrm{AX}$ after formation of X-ray-induced DNA double-strand breaks in human blood lymphocytes. Int J Radiat Biol 2013; 89: 424-432

37 Löbrich $M$, Shibata A, Beucher $A$ et al. gammaH2AX foci analysis for monitoring DNA double-strand break repair: strengths, limitations and optimization. Cell Cycle 2010; 9: 662-669

38 Muslimovic A, Johansson P, Hammarsten O. Measurement of H2AX Phosphrylation as a Marker of Ionizing Radiation Induced Cell Damage. In: Nenoi M (Ed.): Current Topics in Ionizing Radiation Research. Rijeka: InTech; 2012: 3-20 